\title{
Current Trends and Issues in Albanian Language Use
}

\author{
Prof. Assoc. Dr. Rrezarta Draçini
}

Shkodra University, Albania

Dr. Rezearta Murati

Shkodra University, Albania

Doi: 10.2478/jesr-2018-0008

\begin{abstract}
Language is an instrument for communication and it has the obligation to serve people improving it. But in fact there are moments when language and its rules, decided by a group of people, goes against this purpose, creating so a disorientation between the users and misapprehension of the messages transmitted. In the Orthography of Albanian Language printed in 1973 (p.23) is written "The foreign names has to be written according to the tradition of their use in Albanian taking in consideration the pronunciation in their relative language." Last 20 years in publications, periodic and visual medias in Albania we can note that the Albanian language is in crossroad between: a rule imposed in a situation of complete isolation and the actual situation of multiple contacts that makes the rule a barrier. Nowadays the same names are written in different forms losing so the correlation with the original and causing a enormous problem not only linguistic but cultural and interpersonal, too. For example referring to high school textbook of literature we will find the names of the American authors as pronounced, in the following forms: Teodor Ruthk, Robert Louell, Xhon Berrimen, Robert Krili, Allen Ginsbergu, Majkell Meklur, Xhek Spicer, Diane Uakoski etc. If an Albanian student would like to prepare a homework and he goes to search in internet information or to find bibliography about these authors, will be impossible to have results, because these names don't exist in that form. According to the EU and UN norms, the names must be written in respect of the original form. Therefore the Albanian language should reflect social, political and cultural changes of the society, an open society needs an flexible and opened language because as Hudson said "Linguistics ignores the society for its harm".
\end{abstract}

Keywords: Albanian language, rule, English name, problem, current trends, original form.

The language is a means of communication and so it should serve people to facilitate its possibilities. However, indeed, there are moments when language with its rules set by different groups of people goes in against this mission by creating a discord for users and a misunderstanding of messages transmitted. Such a thing is currently happening with the Albanian in the usage of foreign proper names. In the editions of the 20 recent years, in the media inside and abroad, it is obvious that the Albanian is at the crossroad of a written rule of an isolation situation and a current situation of multifaceted contacts, in which this rule is not used or it is badly used. Result: the same foreign proper names appear in different forms, losing the connection with the original and creating a huge problem not only at the interlinguistic level, but also in interpersonal communication.

In The Albanian spelling (orthography) of the 1973 edition (pg 23) it is written: "Foreign proper names should be written basing on the tradition of their usage in Albanian and taking into consideration the pronunciation in the respective language.".Meanwhile, in The Standard Albanian published in 2002 by Rami Memushaj, it is added: "Foreign proper names appearing for the first 
time will be given as they are pronounced in Albanian by putting in brackets their original version. Proper names of languages that do not use the Latin alphabet, will be written as pronounced, without being given in brackets their writing with any other alphabet, even when they appear for the first time, such as: Gëte ( Goethe), Shekspir (Shakespeare) etc" pg 164, 216, Standard Albanian, Remi Memushaj, Tirane 2002. The problem has the beginning at the rule which is not comprehensive because it excludes a huge number of names that are not written in the Latin alphabet, leaving room for its misuse.

The rule is based on a facility in reading for Albanian users, while it is forgotten the importance of the written form. The right transcription of a foreign word in Albanian and afterwards, its graphic presentation is not easy, anyway. So, there is a huge difference between Albanian and English in phonological systems, there is a discrepancy between two languages: Albanian has seven vocal phonemes, hile English has twelve pure vocals. So, English has /æ/ (land) that Albanian does not have but it suits to /ä/. Writing English phonemes with Albanian letters has caused problems, words distortions. (Shykrane Germmizaj, Transcription in English-Albanian dictionaries, Philology 8, Pristine University, Pristine 2000, pg 138-155; The same thing can be stated about consonants, especially when they are in groups. Their transcription in Albanian is difficult and leaves room for mistakes such as: in German we have Ködderitzsch that in Albanian occurs as Këderiç. The group of $t z s c h$ consonants turns into ç. Separate issue is the writing of English iproper names with the / $\mathrm{w} /$ phoneme in their radical. According to the Albanian spelling, $/ \mathrm{w} /$ is replaced with $/ \mathrm{u} /$. However, the equality between $/ \mathrm{w} /$ and $/ \mathrm{u} /$ causes problems when we deal with German words, because in German /w/ is /v/. This problem has been well-explained by Vesel Nubiu in the article: "Writing foreign names in Albanian" pg 287-292, Tirane.

"A written mistake is worse than a pronunciation mistake. Writing remains while reading can be repaired." (Thanas Shkurti, Science Academy of Albanian Republic, Tirane 1973, pg 315)

Despite some special cases, in all Albanian publications, the spelling rule of foreign proper names is not applicable and it is misused. The same name is written (spelled) in different ways from different users according to the knowledge of the respective language by the author or the speaker. In the recent editions, in school books and in other studies, the proper names are written in different ways according to the translator and researcher's desire and knowledge For example, a writer's name $(X X X X)$ is written either in his original form or in two different variants: Xhejms Xhojs or Xheims Xhois.

The result: we have two different transcriptions for the same name. We have to do here with an exact linguistic mess. In this case we deal with a real linguistic tangle. We have found a huge number of names that are wrongly spelled in Albanian, consequently, they are also wrongly written f.ex: Los Anxhelos (it should be Los Anxheles), Meriland (it should be Merilend, Zyrih (it should Cyrih). The ex- American ambassador's name Joseph Limprecht is written and spelled in media in two versions: Zhozef or Jozef, while it should be Xhozef. Another case is the name Albright that occurs in: Olbrajt or Ollbrait. The same foreign proper name, passing from one user to another is transformed and it loses its original form, passing gradually to another name.

In order to bring a concrete part of the linguistic reality related to this case, we have investigated a huge number of editions of the post-90's: Albanian author books, foreign author books translated into Albanian, periodic press and visual media. We have had a wide overview because we really wanted to know the situation of foreign proper names that are being used in Albanian. Actually, the result was the one we expected.Problems are multifaceted: phonetic, grammatical, lexical and semantic ones.

In Albanian authorial books, in some cases, the name is given according to the spelling rule but there are more cases of the rule deviation; when the original is written in parentheses or even when it is given only the original version, without the transcription in Albanian. In translations, the name is given in the original version without following the Albanian spelling rule.

In school books, the authors' names are given in different ways, depending on the authors that have translated them. So, in one book are given these names: Delmor Zhvarc, Teodor Ruthk, Robert Louell, Xhon Berrimen, Zhirom Salinger, Xhon Apdajk etc. and within the same book we can find their original version, such as ; Allen Ginsberg, Ted Hughes, Mary Suenson, Luis Gluck, etc. 
The use of two different ways of writing the names, especially in scholar books leads to confusion in giving the information that is pretended to be both correct and undisputable. Ky pwrdorim i dy formave tw ndryshme tw shkrimit tw emrave sidomos nw tekstet shkollore krijon konfuzion nw dhwnien e informacionit qw pretendohet tw jetw i saktw dhe i padiskutueshwm. If an Albanian student wants to prepare his homework and he surfs on the internet to find information or bibliography about these authors, it will be impossible to have results, because these names do not exist in that form.

Another huge problem is the accent concerning the spoken language. Albanian has mainly a penultimate accent, which means that the accent stands on the last syllable. The cases when there are exceptions are known from speakers. This rule is not used for foreign proper names. We have two distinctive aerials of the foreign proper words and names (Gjovalin Shkurtaj, features and phenomena of the Albanian language and culture pg,114) On one side, there are speakers within the borders of Albania that try to keep the original accent of words (Ke'vin, El'vis, Pa'dova etc) and on the other side there are speakers of Kosovo and other areas outside Albania that turn the prior penultimate accent into penultimate accent; (Kevi ' $n$, Elvi's, Pado'va etc). There is an obvious tendency of not respecting the Albanian penultimate accent and of putting the emphasis on the prepenultimate accent, while the spelling rule concerns writing and reading normally, putting the emphasis on the penultimate accent (Pado'vë, Gjeno'vë etc)

Violations of Albanian spelling rules for this group of names lead to grammatical problems. They do not follow morpho-syntaxic rules. Foreign proper names are not declined, so they avoid the linguistic rule: "The young man Holden" of Zhirom Salinger, "The bluest eye" of Toni Morrison, "Dharma's nomads" of Xhek Keruak, etc.

The proper names do not follow the rule in the nominative case, definite form. In the nominative case the name occurs the same as the original, violating the Albanian rule. for.ex: Carls Oslon / Carls Osloni.

The Albanian spelling rule is the following: the name turns into Albanian and the ending becomes part of the name. Meanwhile, it is not followed in reality creating a discard form the rule and different graphical demonstrations. The name turns into Albanian and it is followed by a hyphen and then comes the ending. There are some cases when one half of the ending goes with the name and the other half comes after the hyphen: f.ex Louelli-t, Louell-it must be Louellit .

According to our remarks, we notice that the writing of the endings of these names tends to go towards the regulation concerning two forms:

\section{-Allen Ginsbergun}

-Allen Ginsberg-un

These facts should be taken into consideration by the Albanian Inter-academicals Council. While they are wrongly written, these names are also wrongly read, so we have two deviations from the rule, that may be called solecisms. Day after day we face cases like these: we are reading the articles of "Balkans", while it can be said:

-po lexojnë artikujt e gazetës "Ballkan"

- po lexojnë artikujt e së përditshmes "Ballkan"

-po lexojnë artikujt e organit "Ballkan"

Examples where the apposition "Balkans" saves the rule, or by writing the title of the journal using the right endings of the indirect cases :

- e Ballkanit

-të Ballkanit

-me Ballkanin

-prej Ballkanit

Acronyms: FBI, KFOR etc, that have their own deviations in writing and reading are another issue.

The facts that we mentioned made us reopen an issue which is essential in linguistic theories: the speking community makes the language or that community is obliged to use the language and its rules. According to the socialinguistic theories, the language is a means of communication that serves people to fulfill their requirements. (Sociolinguistics, Gjovalin Shkurtaj pg 98).

The written usage of the language also encourages a special and a new undercompetence. The recognition of inversial connections between oral presentation and graphical representation is 
undoubtedly an important side to be studied from the "language-society" interactions point of view.

"Linguistics can't be theorically compelling: its duty is both to describe and explain the phenomena and to notice the language directions" (Shezai Rrokaj, Cases of the Albanian, pg 216). While nowadays, the linguistic rule is being imposed to the natives, so to the Albanian users in an arbitrary way. The fact that the rule is not being followed means that its users do not feel so comfortable and they are so disorganised. Not only the Albanians, but also the intellectuals and linguists do not take into consideration this rule. Then, in this case,we can not "blame" the user, but we must blame the linguistic rule that is inappropriate. So, the use of names in their original version has become irreversible in nowadays Albanian editions. It is even stated from other researchers: "There are plenty cases of violation of rules in this cathegory of names, maybe there are much more than in cases of its execution." (Gjovalin Shkurtaj, Features and phenomena of the Albanian language and culture, pg 112).

In this situation, it is about time that the linguistcs professionally interferred and reviewed the rule of Albanian spelling about foreign proper names because the speaking community has made it clear that that rule does not fulfill their requirements to communicate. Moreover, the experience of other countries demostrates that proper names are written in their original version." In " The writing of proper names in the Albanian standard language" researcher Armin Hecer (Hezer) proposes a review of spelling rules for foreign proper nouns in accordance with the Europian Community norm, and also in accordance with the United Nations Organisation,according to which the original version of the name should be respected. "As we want to be part of the European Comunity, we should obbey to its rules.

"It is important to understand that the linguist's work does not mean to tell the speaker which form must be used in Albanian and which not, because even if he did, he would not have so much success. It belongs only to the users to naturally choose one or another way of writing and speaking communication." Shezai Rrokaj, Albanian standard on th eve of the 21-st century, pg 220).

According to this saying, we can state that until now Albanian language users have shown that the rule about foreign proper names is not practical in use, and it should be done something before facing a complicated situation where foreign proper names will radically change and it would not be possibile to go back to normal.

We would prefer to close our study with a saying of Hadson in his book: "Sociolinguistic" where it is written: "Linguistics ignores the society for its harm".

\section{References}

RRokaj SH.( Tiranë 2007) Shqipja standarte në pragun e shekullit të ri, në "Çështje të Gjuhës Shqipe"

Shkurtaj GJ.(Tiranë 2003) Sociolinguistika

Shkurtaj GJ. (Tiranë 2004) Etnolinguistika

Hudson. A. R (Tiranë 2002) Sociolinguistika

Memushaj R. (Tiranë 2003) Shqipja Standarte

Akademia e Shkencave (Tiranë 1973) Drejtshkrimi I Gjuhës Shqipe

Kostallari A. (Tiranë 1973) Gjuha e sotme letrare shqipe dhe disa probleme themelore të drejtshkrimit të saj.

Shkurtaj Gj (Tiranë 2003) Kahe dhe dukuri të kulturës së gjuhës shqipe .

Gërmizaj Sh (Prishtinë 2000) Traskriptimi I fjalëvë në fjalorët anglisht- shqip në Filologji 8 botim I UNiversitetit të Prishtinës ,Fakulteti I Filologjisë

Shkurtaj Gj (Tiranë 2001)Emrat e përveçëm të huaj dhe drejtshkrimi I tyre në gjuhën shqipe,Gjuha jonë,3$4 / 2001$, fq $73-78$

Shkurtaj GJ (Tiranë 2000)Drejtshkrimi dhe drejtshqiptimi në mediat e sotme të shkruara dhe të folura ,Gjuha jonë, $1-2 / 2000$, fq 31-40

Kulturë e gjuhës 1 (Prishtinë 2003)Shoqata e gjuhës shqipe e Kosovës

Hecer A ,Shkrimi i emrave të përveçëm në gjuhën letrare shqipe" Gjuha e jonë , 1-4/1993 fq 40-45

Emil Lafe,Sistemi I traskriptimit nga gjermanishtja ne gjuhën shqipe, Gjuha Jonë 2/1991, Akademia e Shkencave e RP të Shqipërisë, Tiranë

Vjollca Kalaja, Drejtshkrimi dhe drejshqiptimi I emërtimeve gjeografike,Gjuha jonë,1/1991,Akademia e Shkoencave e RP të Shqipërisë, Tiranë

Vesel Nubiu, Të shënuarit e emrave të huaj në gjuhën shqipe, Gjuha Jonë, Tiranë fq 287-292. 